\title{
Angiogenin Reduces Immune Inflammation via Inhibition of TANK-Binding Kinase 1 Expression in Human Corneal Fibroblast Cells
}

\author{
Seung Hoon Lee, ${ }^{1,2}$ Kyoung Woo Kim, ${ }^{1}$ Kyong-Mi Min, ${ }^{3}$ Kyu-Wan Kim, ${ }^{3}$ \\ Soo-Ik Chang, ${ }^{3}$ and Jae Chan Kim ${ }^{1}$ \\ ${ }^{1}$ Department of Ophthalmology, College of Medicine, Chung-Ang University Hospital, 224-1 Heukseok-dong, Dongjak-Gu, \\ Seoul 156-755, Republic of Korea \\ ${ }^{2}$ Department of Medicine, Graduate School, Chung-Ang University, Seoul, Republic of Korea \\ ${ }^{3}$ Department of Biochemistry, Chungbuk National University, 52 Naesudong-ro, Heungdeok-gu, Cheongju, \\ Chungbuk 361-763, Republic of Korea \\ Correspondence should be addressed to Jae Chan Kim; jck50ey@kornet.net
}

Received 31 December 2013; Revised 24 March 2014; Accepted 24 March 2014; Published 17 April 2014

Academic Editor: Fulvio D’Acquisto

Copyright (c) 2014 Seung Hoon Lee et al. This is an open access article distributed under the Creative Commons Attribution License, which permits unrestricted use, distribution, and reproduction in any medium, provided the original work is properly cited.

\begin{abstract}
Angiogenin (ANG) is reportedly multifunctional, with roles in angiogenesis and autoimmune diseases. This protein is involved in the innate immune system and has been implicated in several inflammatory diseases. Although ANG may be involved in the anti-inflammatory response, there is no evidence that it has direct anti-inflammatory effects. In this study we sought to determine whether ANG has an anti-inflammatory effect in human corneal fibroblasts (HCFs) exposed to media containing tumor necrosis factor-alpha (TNF- $\alpha$ ). We found that ANG reduced the mRNA expression of interleukin- 1 beta (IL- $1 \beta$ ), $-6,-8$ and TNF- $\alpha$ receptors (TNFR) 1 and 2. In contrast, ANG increased the mRNA expression of IL-4 and -10. Protein levels of TANK-binding kinase 1 (TBK1) were reduced by ANG in HCFs treated with TNF- $\alpha$. Moreover, ANG diminished the expression of IL- 6 and -8 and monocyte chemotactic protein- (MCP-) 1. The protein expression of nuclear factor- $\kappa \mathrm{B}$ (NF- $\kappa \mathrm{B})$ was downregulated by ANG treatment. These findings suggest that ANG suppressed the TNF- $\alpha$-induced inflammatory response in HCFs through inhibition of TBK1mediated NF- $\kappa$ B nuclear translocation. These novel results are likely to play a significant role in the selection of immune-mediated inflammatory therapeutic targets and may shed light on the pathogenesis of immune-mediated inflammatory diseases.
\end{abstract}

\section{Introduction}

Ocular inflammation is one of the main causes of blindness and visual disturbance. A number of ocular inflammatory diseases cause visual impairment and chronic immunemediated inflammation in the eye can lead to blindness [1-4]. Inflammation is a main component in the pathophysiology of several ocular diseases including corneal and autoimmune diseases. It has generally been accepted that inflammatory cytokines and chemokines are significantly increased in many ocular diseases and immune rejection of corneal transplantation $[5-8]$.
The corneal stroma is a thick, transparent layer that is frequently subjected to the inflammatory response [9]. Chronic inflammation of corneal fibroblasts causes corneal scarring, neovascularization, edema, opacity, injury, ulceration, and ultimately impaired vision and blindness [4, 9-11]. Human corneal fibroblasts (HCFs) in the corneal stroma perform a significant function in the control of local immune and inflammation [12]. It has been widely reported that corneal fibroblast cells act as sentinel cells of the immune system and participate in the regulation of stromal inflammation through the production of cytokines and chemokines [13-15]. Corneal fibroblast cells secrete proinflammatory cytokines 
and chemokines including interleukin (IL)-6 and IL-8 in response to external inflammatory stimuli $[12,15,16]$.

Tumor necrosis factor- $\alpha$ (TNF- $\alpha$ ) is a cytokine involved in the inflammatory response that binds two receptors and tumor necrosis factor receptors (TNFR) 1 and 2. It has been demonstrated that TNF- $\alpha$ plays a critical role in corneal inflammation [17]. TNF- $\alpha$ promotes nuclear factor- $\kappa \mathrm{B}$ (NF$\kappa \mathrm{B})$ translocation, and the NF- $\kappa \mathrm{B}$ signaling pathway, which is found in all mammalian cell types, comprises several genes that influence immune and inflammatory responses $[18,19]$. $\mathrm{NF}-\kappa \mathrm{B}$ is activated by phosphorylation of the regulatory protein I-kappa-B (I $\kappa \mathrm{B})$ and TANK-binding kinase 1 (TBK1). TBK1 promotes NF- $\kappa$ B activation and may act downstream of the NF- $\kappa \mathrm{B}$ transcriptional pathway $[20,21]$. It is well documented that TBK1 inhibitors decrease inflammation [22].

Angiogenin (ANG) is a $14.4 \mathrm{kDa}$ single chain protein containing 123 amino acids. Several studies have demonstrated its function with respect to immunity. This protein is a component of tears and protects the ocular surface as it is an antimicrobial peptide $[23,24]$. ANG mRNA expression and ANG protein concentrations in serum are increased during the inflammatory response $[25,26]$. Serum ANG was found to be increased in patients with inflammatory bowel disease, and ANG mRNA expression was shown to be elevated by TNF- $\alpha$ and IL-1 $\beta[27,28]$. ANG was also shown to have bactericidal activity [29] and has been reported to be a microbial recognition protein related to innate immunity [30]. This evidence suggests that ANG may play a role in modulating the inflammatory response.

We hypothesized that ANG has an inhibitory effect on the inflammatory response in the ocular surface. The aim of this study was to determine whether ANG has an antiinflammatory effect in HCFs treated with TNF- $\alpha$. Thus, we attempted to clarify the molecular activity of ANG underlying its inhibition TNF- $\alpha$ mediated transduction, which involves the production of TBK1 and nuclear translocation of NF- $\kappa \mathrm{B}$.

\section{Methods}

2.1. Isolation and Primary Culture of Human Corneal Fibroblast Cells. Human corneal donor tissues were obtained during penetrating keratoplasty. The corneal epithelium was eliminated and then the corneal fibroblast cells were detached from explant tissue. The corneal tissues were rinsed with phosphate-buffered saline (PBS) mixed with 5\% penicillinstreptomycin. After the corneal epithelium was eliminated, the corneal stroma was cut into explants of approximately $1 \mathrm{~mm}^{3}$. Each piece of explant was placed on a culture dish and immersed in culture medium for one week. The HCFs were then subcultured by trypsin digestion. HCFs were cultured in alpha-minimum essential medium $(\alpha-$ MEM) (Invitrogen-Gibco, USA) containing 10\% FBS and 1\% penicillin-streptomycin. The cells were maintained at $37^{\circ} \mathrm{C}$ under $5 \% \mathrm{CO}_{2}$ and used for experiments after three to five passages. The study protocol and informed consent were approved by the institutional review board of the Chung-Ang
University Hospital. This study conformed to the tenets of the Declaration of Helsinki.

2.2. Cell Treatment. HCFs were cultured in six-well plates for three days. They were washed twice with PBS. The medium of confluent corneal fibroblast cells was changed to serumfree MEM for one day before treatment. The cells were treated with TNF- $\alpha$ purchased from PROSPEC $(20 \mathrm{ng} / \mathrm{mL})$ for eight hours, and with or without ANG $(2 \mu \mathrm{g} / \mathrm{mL})$ at the last 30 minutes of incubation with TNF- $\alpha$. ANG was obtained from the Department of Biochemistry at Chungbuk National University and the identity of the purified ANG has been confirmed by western blotting with ANG specific antibodies by methods described in a previous report [31]. The biological activity of the purified ANG has also been confirmed by its nuclear translocation in HUVE cells by procedure described in detail [31]. The purification and endotoxin levels of recombinant ANG expressed in E. coli are shown in Supplementary Figures 1 and 2 (see the Supplememtery Material available online at http://dx.doi.org/10.1155/2014/861435). The cells were then collected for total RNA isolation and protein extraction.

2.3. RNA Isolation and Real-Time RT-PCR. Total RNA was isolated from cultured HCFs using FavorPrep Tri-RNA reagent, according to the manufacturer's protocols. The quantity and quality of the RNA were determined using a NanoDrop ND-1000 spectrophotometer (ND-1000, NanoDrop Technologies, Inc. Wilmington, DE, USA). Singlestranded complementary DNA (cDNA) was synthesized from 500 ng of total RNA using a cDNA synthesis kit (Takara Bio Inc., Otsu, Japan). Real-time RT-PCR was conducted using the CFX96 Real-Time PCR Detection System (Bio-Rad, Hercules, CA, USA) in a total volume of $20 \mu \mathrm{L}$ containing $10 \mu \mathrm{L}$ of SYBR Premix Ex Taq (Takara Bio Inc., Otsu, Japan), diluted cDNA template, and forward and reverse primers. The primer sequences and product size are listed in Table 1. The PCR amplification for selected genes was run for 40 cycles. Gene expression was analyzed by realtime reverse transcriptase polymerase chain reaction (RTPCR). Real-time PCR quantification was done in triplicate for each sample and the mean was calculated. Expression levels were analyzed by RT-PCR using values of glyceraldehyde-3phosphate dehydrogenase (GAPDH) as a reference.

2.4. Immunodot Blot Assay. The expression of 42 human cytokines and chemokines was assessed using a commercially available cytokine assay (RayBio Human Cytokine Antibody Array 3, RayBiotech, Norcross, GA, USA) that utilizes membrane-bound cytokine-specific antibodies to assess the presence of several cytokines in biological fluids. The analysis was conducted according to the manufacturer's instructions. Briefly, membranes were blocked for 30 minutes and then incubated with HCFs culture supernatant for two hours at room temperature. The membranes were washed with Wash Buffer I three times for five minutes each and then with Wash Buffer II twice for five minutes each. After washing, the membranes were incubated with a biotin-conjugated antibody mix 
TABLE 1: PCR primers used in this study.

\begin{tabular}{lccc}
\hline Gene & Sense primer $\left(5^{\prime} \rightarrow 3^{\prime}\right)$ & Antisense primer $\left(3^{\prime} \rightarrow 5^{\prime}\right)$ & PCR product size $(\mathrm{bp})$ \\
\hline GAPDH & CGAGATCCCTCCAAAATCAA & TGTGGTCATGAGTCCTTCCA & 294 \\
IL-1 $\beta$ & CCTGTCCTGCGTGTTGAAAGA & GGGAACTGGGCAGACTCAAA & 150 \\
IL-4 & TGTCTGTTACGGTCAACTCG & ACATTGTCACTGCAAATCGA & 195 \\
IL-6 & TTCGGTCCAGTTGCCTTCTC & GAGGTGAGTGGCTCTCTGTG & 122 \\
IL-8 & ACATGACTTCCAAGCTGGCCG & TTTATGAATTCTCAGCCCTC & 303 \\
IL-10 & GCCTAACATGCTTCGAGATC & TGATGTCTGGGTCTTGGTTC & 206 \\
TNFR1 & GTGCTGTTGCCCCTGGTCAT & GCTTAGTAGTAGTTCCTTCA & 163 \\
TNFR2 & AAACTCAAGCCTGCACTC & GGATGAAGTCGTGTTGGAGA & 209 \\
TBK1 & TTCTGGAAGTCCATACGCAT & ACTGGTGATCTCTATGCTGT & 237 \\
\hline
\end{tabular}

for two hours, and then streptavidin-conjugated peroxidase was added for two hours at room temperature. The membranes were subsequently washed thoroughly and exposed to chemiluminescence. The membranes were visualized using the ECL Plus detection system and ChemiDoc XRS (BioRad Laboratories, Inc., Berkeley, CA, USA). The densities for individual spots were calculated using ImageJ software (Wayne Rasband, National Institutes of Health, USA). The relative expression ratio was determined by subtraction of the background signal and comparison with positive controls on the membrane. Positive controls visible within each array were used for comparison.

2.5. Nuclear and Cytosolic Protein Extractions. HCFs were washed and scraped with cold PBS. The cells were lysed in buffer A (10 mM HEPES (pH 7.9), $10 \mathrm{mM} \mathrm{KCl,} 0.1 \mathrm{mM}$ EDTA, $0.1 \mathrm{mM}$ EGTA, $1 \mathrm{mM}$ DTT, $0.5 \mathrm{mM}$ PMSF, and $5 \mu \mathrm{g} / \mathrm{mL}$ Leupeptin) and left on ice for $15 \mathrm{~min}$. After $10 \%$ NP-40 was added to the sample, the cytosolic fraction was collected by centrifugation at $14,000 \mathrm{rpm}$ for $5 \mathrm{~min}$ at $4^{\circ} \mathrm{C}$. The nuclear fraction was resuspended in buffer $\mathrm{C}(20 \mathrm{mM}$ HEPES (pH7.9), $0.4 \mathrm{n} \mathrm{NaCl}, 1$ mM EDTA, 1 mM EGTA, 1 mM DTT, $1 \mathrm{mM}$ PMSF, and $10 \mu \mathrm{g} / \mathrm{mL}$ Leupeptin) and left on ice for $30 \mathrm{~min}$, then the nuclear fraction was collected by centrifugation at $14,000 \mathrm{rpm}$ for $5 \mathrm{~min}$ at $4^{\circ} \mathrm{C}$.

2.6. Western Blot Analysis. Nuclear proteins and total cell lysates were separated by $10 \%$ sodium dodecyl sulfate polyacrylamide gel electrophoresis (SDS-PAGE) and electrophoretically transferred to a polyvinylidene fluoride membrane (PVDF; Merck Millipore, Billerica, MA, USA) at $100 \mathrm{~V}(1 \mathrm{~h})$ in buffer containing $0.3 \%$ Tris, $1.4 \%$ glycine, and $20 \%$ methanol using a wet-blotting apparatus (MiniPROTEAN Tetra cell; Bio-Rad, Hercules, CA, USA). The PVDF membrane containing the transferred proteins was blocked with 5\% BSA in PBS for one hour at room temperature. Primary monoclonal antibodies against human TBK1 (Abcam, Inc.) and NF- $\kappa$ B (Bioworld Technology, Inc.) diluted in PBS $(1: 1000)$ were applied to the PVDF membrane and incubated overnight at $4^{\circ} \mathrm{C}$. Secondary antibodies diluted in PBS $(1: 2000)$ were subsequently applied to the PVDF membrane and incubated for $1 \mathrm{~h}$ at room temperature. The PVDF membrane was washed four times (10 min each) with Tris-buffered saline (TBS; $50 \mathrm{mM}$ Tris $\mathrm{HCl}$ pH 7.5, $150 \mathrm{mM}$
$\mathrm{NaCl}$ ) containing $0.1 \%$ Tween 20 . The binding of specific antibodies was visualized using an enhanced chemiluminescence western blotting detection kit (Pierce Biotechnology, Inc., Rockford, IL, USA). Densitometric quantification of the immunoblot was carried out using ImageJ software. The value of each band was normalized to $\beta$-actin or lamin.

2.7. Immunocytochemistry. The HCFs cultured on glass slides were treated with TNF- $\alpha(20 \mathrm{ng} / \mathrm{mL})$ for eight hours. Cells were also treated with or without ANG $(2 \mu \mathrm{g} / \mathrm{mL})$ for 0.5 hours. Cells were then fixed in $4 \%$ paraformaldehyde for $15 \mathrm{~min}$ at room temperature. After being permeabilized by incubation with $0.5 \%$ Triton X-100 for $15 \mathrm{~min}$ at room temperature, the slides were incubated with anti-NF- $\kappa \mathrm{B}$ (diluted to $1: 50$ in PBS, Bioworld Technology, Inc.) for $1 \mathrm{~h}$ at room temperature. Glass slides were incubated with secondary antibody for $1 \mathrm{~h}$ at room temperature. At each step slides were washed three times ( 5 min each) with PBS. Cover slips were mounted on the slides using Vectashield (Vector Laboratories, Burlingame, CA, USA) containing 40,6-diamidino-2phenylindole (DAPI).

2.8. Statistical Analysis. Data are expressed as the mean \pm standard error (SE). Statistical analysis of three separate experiments was conducted using one-way ANOVA followed by a post hoc pairwise comparison adjusted with a Bonferroni correction. Statistical analyses were performed using SPSS software version 19.0 (SPSS Inc., Chicago, IL, USA). Differences were considered statistically significant at $P<0.05$.

\section{Results}

3.1. ANG Inhibits mRNA Expression of Proinflammatory Cytokines and Promotes mRNA Expression of AntiInflammatory Cytokines in HCFs. In order to determine whether ANG can reduce the inflammatory response in HCFs, TNF- $\alpha(20 \mathrm{ng} / \mathrm{mL}, 8 \mathrm{~h})$ was added to the culture media and then cells were cultured in the presence or absence of ANG $(2 \mu \mathrm{g} / \mathrm{mL}, 30 \mathrm{~min})$. Real-time PCR was conducted to investigate the effects of ANG treatment on the mRNA expression of proinflammatory (IL-1 $\beta,-6$, and -8 ) and anti-inflammatory cytokines (IL-4 and -10). The expression of proinflammatory cytokines (IL-1 $\beta,-6$, and -8) induced by TNF- $\alpha$ treatment was reduced significantly 

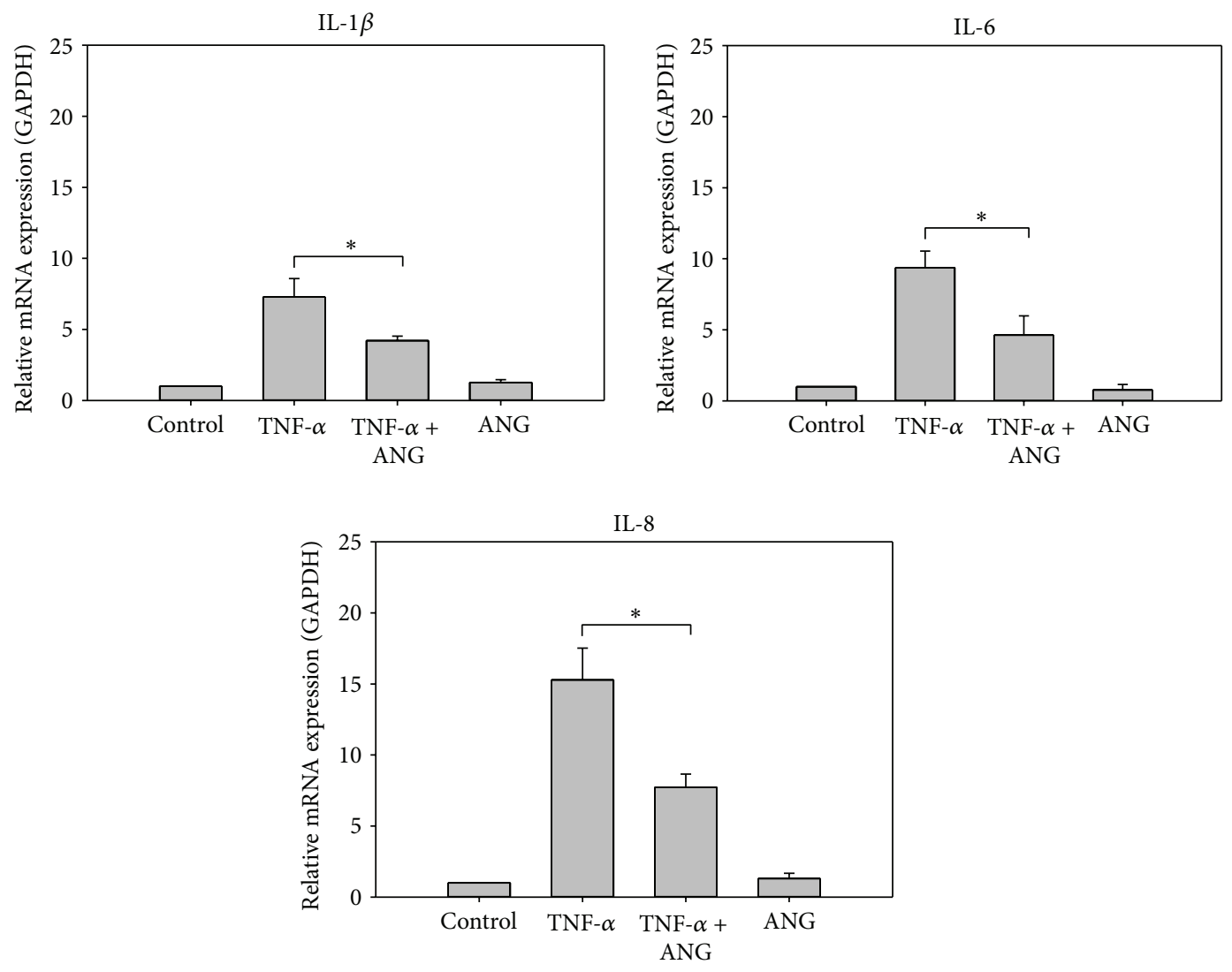

(a)
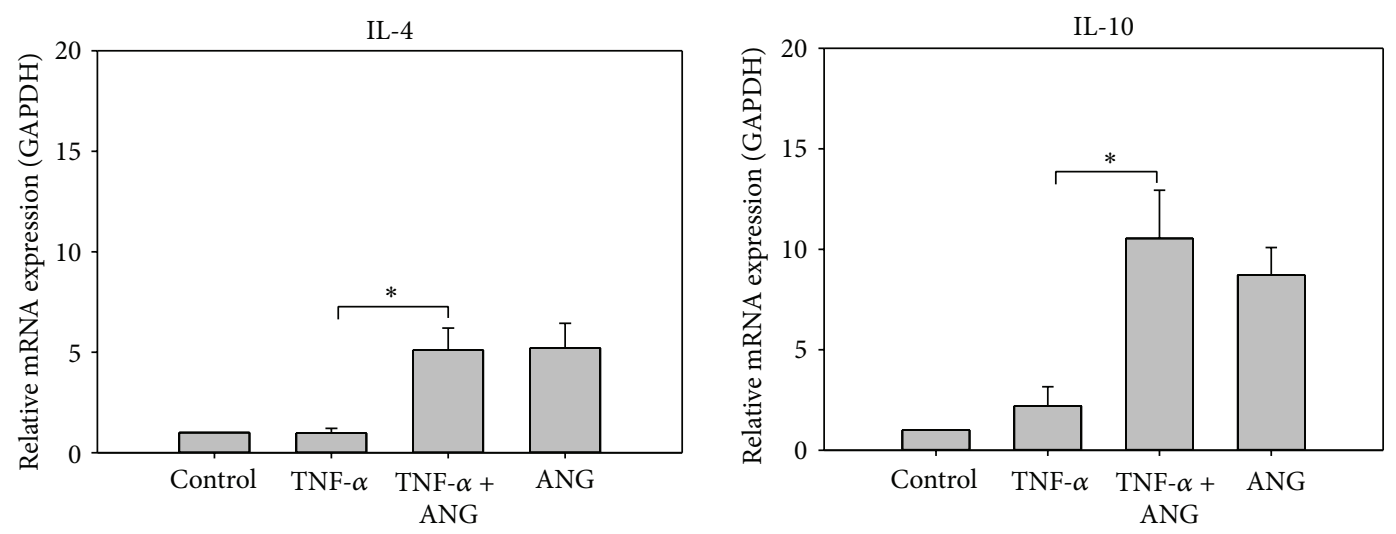

(b)

FIGURE 1: Real-time PCR analyses of proinflammatory cytokines and anti-inflammatory cytokines in HCFs. (a) The relative level of IL-1 $\beta$, -6 , and -8 mRNA was diminished by ANG treatment. ANG treatment alone did not affect the mRNA expression of proinflammatory cytokines. (b) The relative expression of IL-4 and -10 mRNA was increased by ANG treatment. ANG treatment alone increased the mRNA expression of IL-4 and -10. The experiments were performed in triplicate $\left({ }^{*} \mathrm{P}<0.05\right)$.

in cells treated with ANG (Figure 1(a)). ANG treatment alone did not exert influence on the mRNA expression of proinflammatory cytokines. Moreover, the mRNA expression of anti-inflammatory cytokines (IL-4 and -10) was increased significantly after ANG treatment (Figure 1(b)). ANG treatment alone increased the mRNA expression of IL-4 and -10 .
3.2. ANG Suppresses the Expression of Inflammatory Cytokines and Chemokines in HCFs. Immunodot blot assays were conducted to determine whether ANG decreases inflammatory cytokines and chemokines in media. Treatment with TNF- $\alpha$ promoted the expression of inflammatory cytokines and chemokines such as IL- 6 and -8, growth-related proteins (GRO), growth-related proteins-alpha (GRO- $\alpha)$, and 


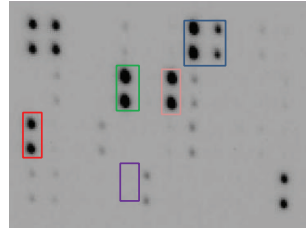

Control

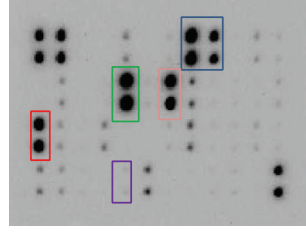

TNF- $\alpha$

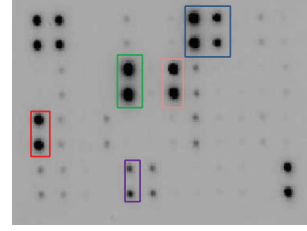

TNF- $\alpha+$ ANG

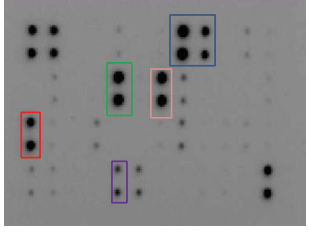

ANG

(a)

\begin{tabular}{|c|c|c|c|c|c|c|c|c|c|c|c|}
\hline $\mathrm{a}$ & $\mathrm{b}$ & c & $\mathrm{d}$ & $\mathrm{e}$ & $\mathrm{f}$ & g & $\mathrm{h}$ & $\mathrm{i}$ & j & $\mathrm{k}$ & 1 \\
\hline Pos & Pos & $\mathrm{Neg}$ & $\mathrm{Neg}$ & ENA-78 & GCSF & GM-CSF & GRO & GRO- $\alpha$ & I-309 & IL- $1 \alpha$ & IL- $1 \beta$ \\
\hline Pos & Pos & $\mathrm{Neg}$ & $\mathrm{Neg}$ & ENA-78 & GCSF & GM-CSF & GRO & GRO- $\alpha$ & I-309 & IL- $1 \alpha$ & IL- $1 \beta$ \\
\hline IL-2 & IL-3 & IL-4 & IL-5 & IL-6 & IL-7 & IL-8 & IL-10 & IL-12p40p70 & IL-13 & IL-15 & IFN- $\gamma$ \\
\hline IL-2 & IL-3 & IL-4 & IL-5 & IL-6 & IL-7 & IL-8 & IL-10 & IL-12p40p70 & IL-13 & IL-15 & IFN- $\gamma$ \\
\hline MCP-1 & MCP-2 & МСP-3 & MCSF & MDC & MIG & MIP- $1 \delta$ & RANTES & SCF & SDF-1 & TARC & TGF- $\beta 1$ \\
\hline MCP-1 & MCP-2 & MCP-3 & MCSF & $\mathrm{MDC}$ & MIG & MIP- $1 \delta$ & RANTES & SCF & SDF-1 & TARC & TGF- $\beta 1$ \\
\hline TNF- $\alpha$ & TNF- $\beta$ & EGF & IGF-I & Angiogenin & Oncostatin M & Thrombopoietin & VEGF & PDGF BB & Leptin & $\mathrm{Neg}$ & Pos \\
\hline TNF- $\alpha$ & TNF- $\beta$ & EGF & IGF-I & Angiogenin & Oncostatin $\mathrm{M}$ & Thrombopoietin & VEGF & PDGF BB & Leptin & Neg & Pos \\
\hline
\end{tabular}

(b)

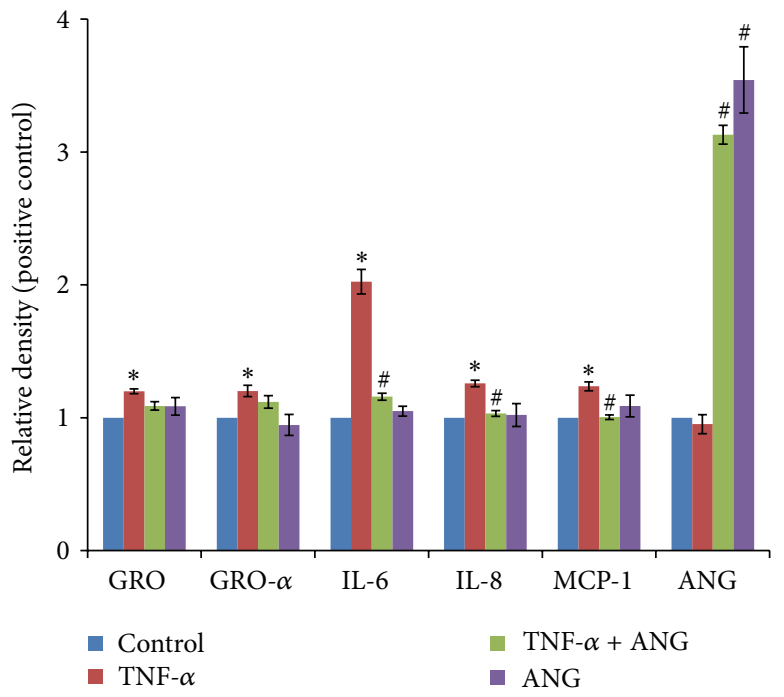

(c)

FIGURE 2: Inflammatory cytokine profiles in HCF culture medium. (a) Treatment with TNF- $\alpha(20 \mathrm{ng} / \mathrm{mL})$ resulted in amplification of five inflammatory cytokines and chemokines (GRO and $-\alpha$, IL- 6 and -8 , and MCP-1). Treatment with ANG $(2 \mu \mathrm{g} / \mathrm{mL})$ resulted in reduction of these inflammatory cytokines and chemokines. Treatment with ANG alone only induced upregulation of ANF area. (b) Custom human growth factor antibody array map. Pos: positive control; Neg: negative control. (c) Relative density of inflammatory cytokines and chemokines. The signal intensities were observed and quantified using a chemiluminescence imaging device. The values presented in the bar graph are the mean \pm SE from triplicate experiments $\left({ }^{*} P<0.05\right.$ versus control cells; ${ }^{\#} P<0.05$ versus TNF- $\alpha$ treated cells). GRO: growth regulated oncogene; MCP: monocyte chemotactic protein. 

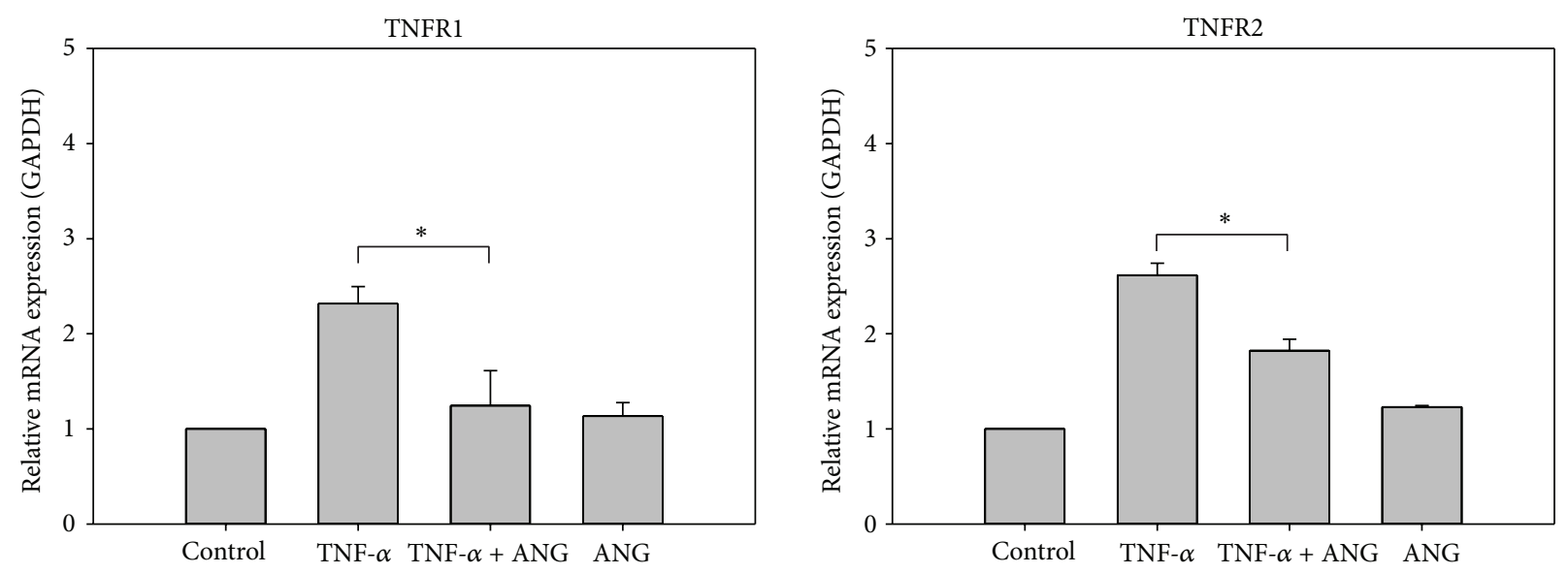

(a)

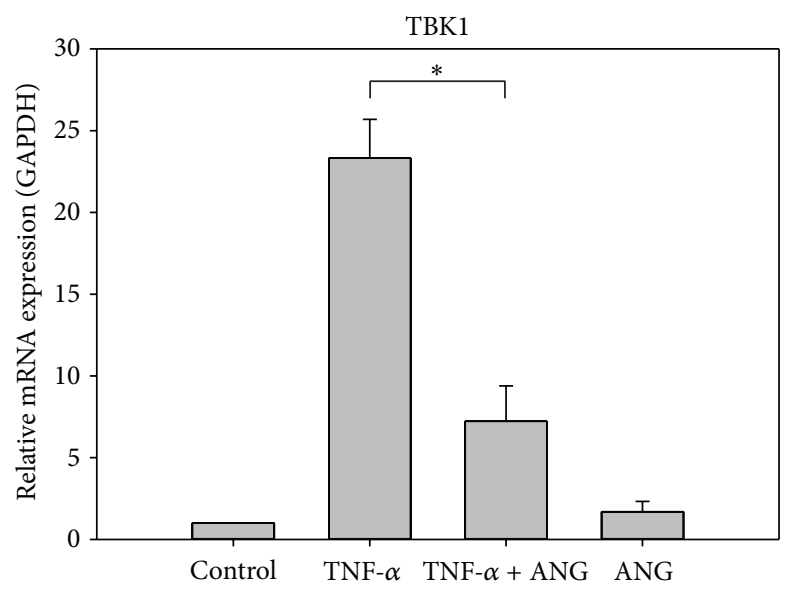

(b)

FIGURE 3: Real-time PCR analysis of TNFR1 and 2 and TBK1 in HCFs. (a) The relative level of TNFR1 and 2 mRNA was diminished by ANG treatment. (b) The relative level of TBK1 mRNA was diminished by ANG treatment. The experiments were performed in triplicate $\left({ }^{*} P<0.05\right)$.

monocyte chemotactic protein- (MCP-) 1. Production of these cytokines and chemokines was downregulated in the presence of ANG, but expression of ANG was upregulated by ANG treatment (Figures 2(a) and 2(b)). We detected significant differences when comparing media before and after ANG treatment with respect to the presence of IL-6 and -8, MCP-1, and ANG (Figure 2(c)). ANG treatment alone increased only ANG expression. The expression of another cytokines was not affected by ANG treatment alone.

3.3. ANG Suppresses TNFR mRNA Expression and TBK1 Production. Real-time PCR was performed to determine whether ANG decreases TBK1 and TNFR1 and 2. TNF- $\alpha$ treatment increased the mRNA expression of TNFR1 and 2, but a significant downregulation was noted after ANG treatment (Figure 3). ANG treatment alone did not affect the mRNA expression of TBK1 and TNFR1 and 2. Western blot analysis showed that ANG reduces the expression of TBK1. TNF- $\alpha$ treatment produced a dose-dependent increase in TBK1 phosphorylation and increased TBK1 expression. After ANG treatment, TBK1 expression was decreased (Figure 4).
ANG treatment alone has little effect on the expression of TBK1.

3.4. ANG Inhibits Nuclear Translocation of NF- $\kappa B$. HCFs were either cultured with TNF- $\alpha(20 \mathrm{ng} / \mathrm{mL}, 8 \mathrm{~h})$ or treated with ANG $(2 \mu \mathrm{g} / \mathrm{mL}, 0.5 \mathrm{~h})$ to examine whether ANG inhibits nuclear translocation of NF- $\kappa \mathrm{B}$. The cells were subjected to immunofluorescent localization of NF- $\kappa$ B. Treatment with TNF- $\alpha$ induced the translocation of NF- $\kappa$ B from the cytosol to nucleus. However, the presence of ANG inhibited the translocation of NF- $\kappa \mathrm{B}$ (Figure 5). ANG treatment alone did not influence the expression of NF- $\kappa \mathrm{B}$ in nucleus.

\section{Discussion}

It is generally believed that ANG is an angiogenic molecule, inducing angiogenesis, cell migration, proliferation, and tumor growth [32-36]. Thus, previous studies have focused on its role in a possible antiangiogenin-based cure for cancer [37-39]. However, ANG is known to function as an antimicrobial peptide and is related to diverse inflammatory diseases and innate immunity [23, 28, 40-42]. Although ANG 


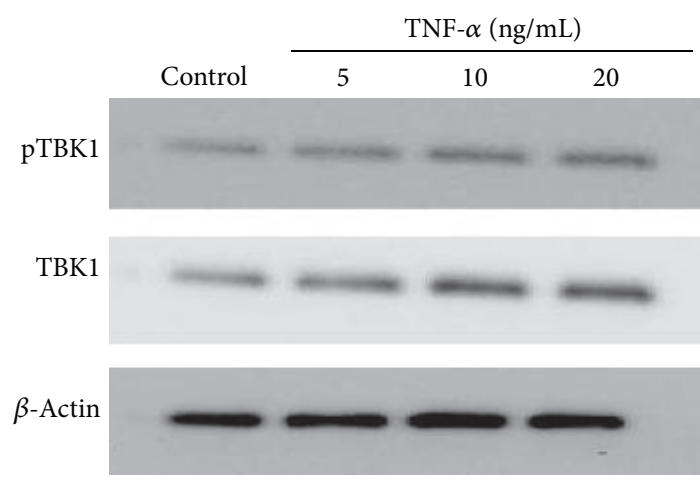

(a)

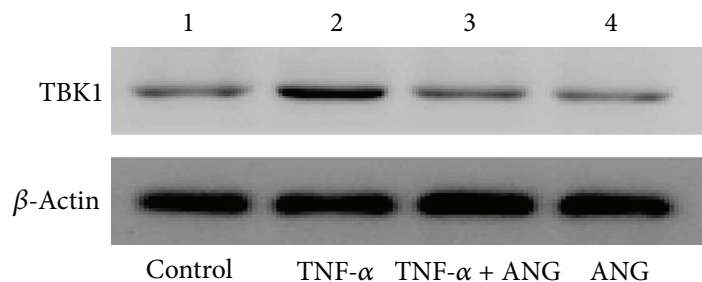

(b)

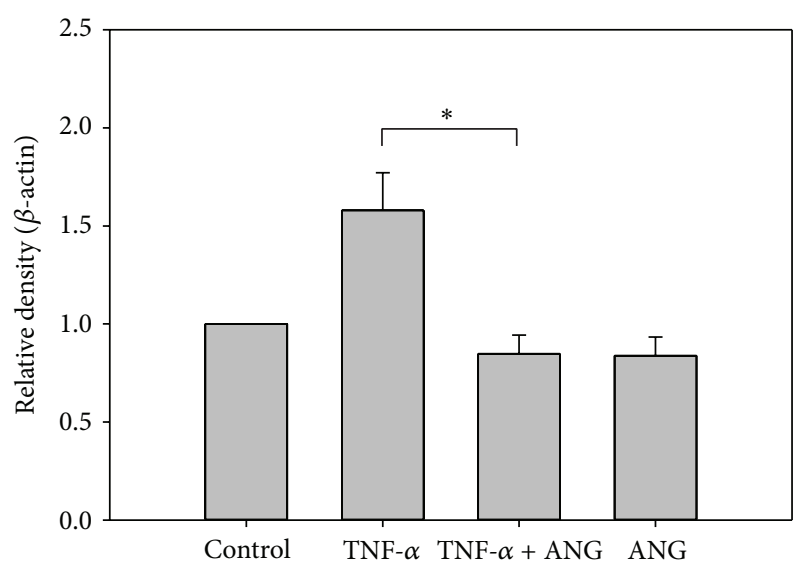

(c)

FIGURE 4: Western blot analyses of TBK1 protein expression and TBK1 phosphorylation (pTBK1). (a) TNF- $\alpha$ treatment increased the expression of TBK1 and TBK1 phosphorylation in HCFs. (b) After ANG treatment, TBK1 protein expression was decreased in HCFs. ANG treatment did not affect TBK1 protein expression. (c) Densitometric analysis of the relative ratio of TBK1 in cells treated with TNF- $\alpha$ only to those treated with TNF- $\alpha+$ ANG. The experiments were performed in triplicate $\left({ }^{*} P<0.05\right)$.

may have anti-inflammatory activity, there is currently no evidence in the literature to support this notion. In this study, we investigated the effect of ANG on inflamed HCFs and discovered a previously unidentified function of ANG in the anti-inflammatory mechanism.

The most substantial finding in our study is that ANG reduced the TBK1-mediated inflammatory response induced by TNF- $\alpha$ treatment. TBK1 is a member of the $\mathrm{I} \kappa \mathrm{B}$ kinase family and is involved in the inflammatory response as it is related to NF- $\kappa \mathrm{B}$ activation [21]. TBK1 also has the ability to modulate the expression of IL- 6 and TNF- $\alpha[43,44]$.
It has been widely demonstrated that TBK1 plays a critical role in inflammatory diseases [45-47]. We have shown that ANG treatment decreased the expression of TBK1 in inflamed HCFs, suggesting that ANG may have possibility of antiinflammatory activity.

It has been suggested that TNF- $\alpha$ induces the production of proinflammatory cytokines and chemokines including IL6 and -8 and MCP-1 $[48,49]$. These cytokines and chemokines are known to cause corneal inflammation [12, 50-54]. IL-6 produced by $\mathrm{T}$ cells and macrophages act as a proinflammatory cytokine. There is evidence that IL- 6 plays a significant role in the acute inflammatory response, escalation of autoimmune reactions, and chronic inflammatory diseases [55-57]. IL- 8 is a chemokine and secreted by macrophages. It has been reported that IL- 8 is involved in acute inflammation and plays a central role in the initiation and maintenance of the inflammatory response in various inflammatory diseases [58-60]. MCP-1 recruits monocytes and memory T cells to the inflammation area. It has been well documented that MCP-1 mediates both acute and chronic inflammation [61]. MCP-1 has also been shown to stimulate IL-6 secretion and NF- $\kappa \mathrm{B}$ activation [62]. One significant finding of this investigation is that IL- 6 and -8 and MCP-1 expression was decreased after ANG treatment, indicating that ANG likely participates in attenuation of the inflammatory response through inhibition of TBK1 expression.

IL-4 and -10 are known to suppress the inflammatory response. IL-4 causes vitalization of triggered B-cell and Tcell proliferation, and IL-10 improves B-cell survival and proliferation. It has been suggested that IL- 4 and -10 have anti-inflammatory activity and repress the expression of proinflammatory cytokines [63-65]. In this study, we found that ANG treatment increased mRNA expression of both IL4 and IL-10. It can therefore be presumed that the expression of IL- 6 and -8 was downregulated by ANG.

TNF- $\alpha$ binds TNFR 1 and 2 and triggers the activation of NF- $\kappa$ B [66]. Phosphorylation of TBK1 and TNFR allows NF$\kappa \mathrm{B}$ nuclear translocation [21], which results in the inflammatory response cascade including amplification of TBK1, IL-6 and -8 , and MCP-1 $[22,67,68]$. NF- $\kappa$ B plays an important role in regulating the immune response and inflammation. It has been reported that NF- $\kappa \mathrm{B}$ is involved in several inflammatory diseases [69-72]. The activation of NF- $\kappa \mathrm{B}$ is inhibited by $\mathrm{I} \kappa \mathrm{B}$ proteins such as TBK1, which deactivate NF- $\kappa$ B by arresting it in the cytoplasm. Our results suggest that ANG may reduce $\mathrm{NF}-\kappa \mathrm{B}$ nuclear translocation through inhibition of TBK1 expression and reduction of TNFR1 and 2 mRNA expression.

A schematic illustration of the anti-inflammatory signaling pathway induced by ANG treatment of HCFs inflamed by TNF- $\alpha$ is shown in Figure 6. TNF- $\alpha$ induces an inflammatory signal by binding TNFR1 and 2 . The inflammatory response is mediated by activation of TBK1, which is required for NF- $\kappa \mathrm{B}$ nuclear translocation. ANG downregulates mRNA expression of IL-1 $\beta,-6$, and -8. Moreover, ANG upregulates mRNA expression of IL- 4 and -10 . ANG also inhibits NF- $\kappa \mathrm{B}$ nuclear translocation through inhibition of TBK1 production. The anti-inflammatory effect induced by ANG results in a reduction of proinflammatory cytokines and chemokines such as MCP-1 and IL- 6 and -8 . 


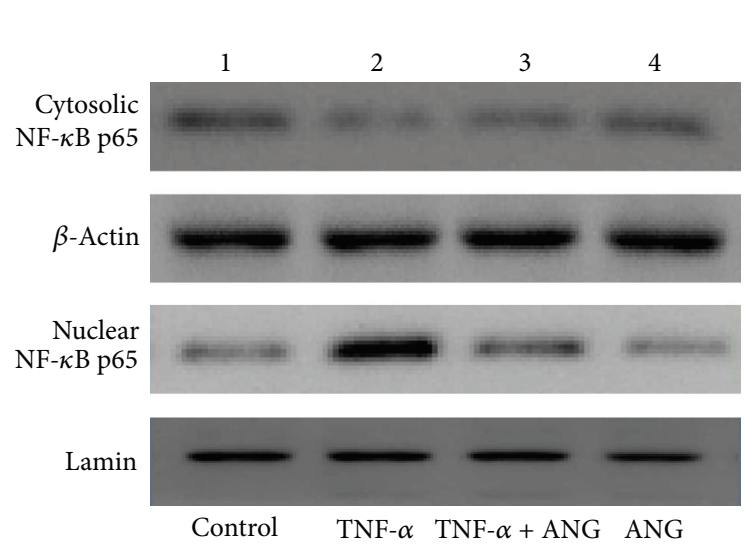

(a)
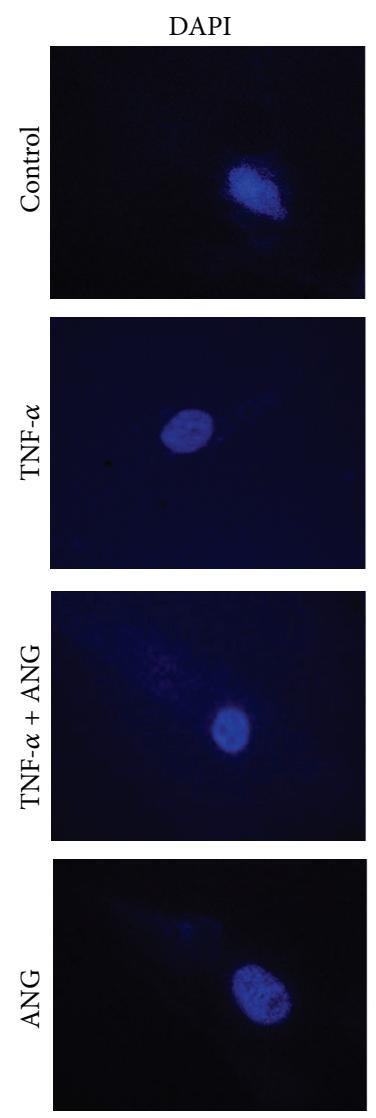

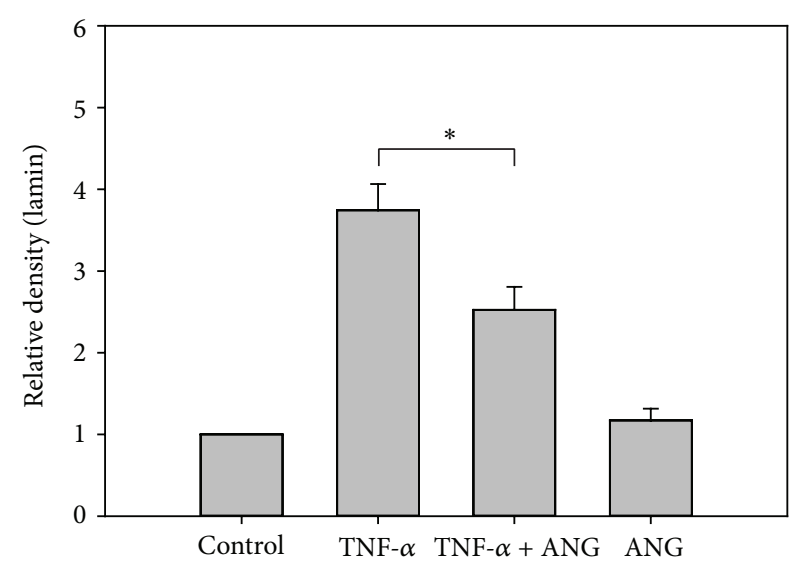

(b)
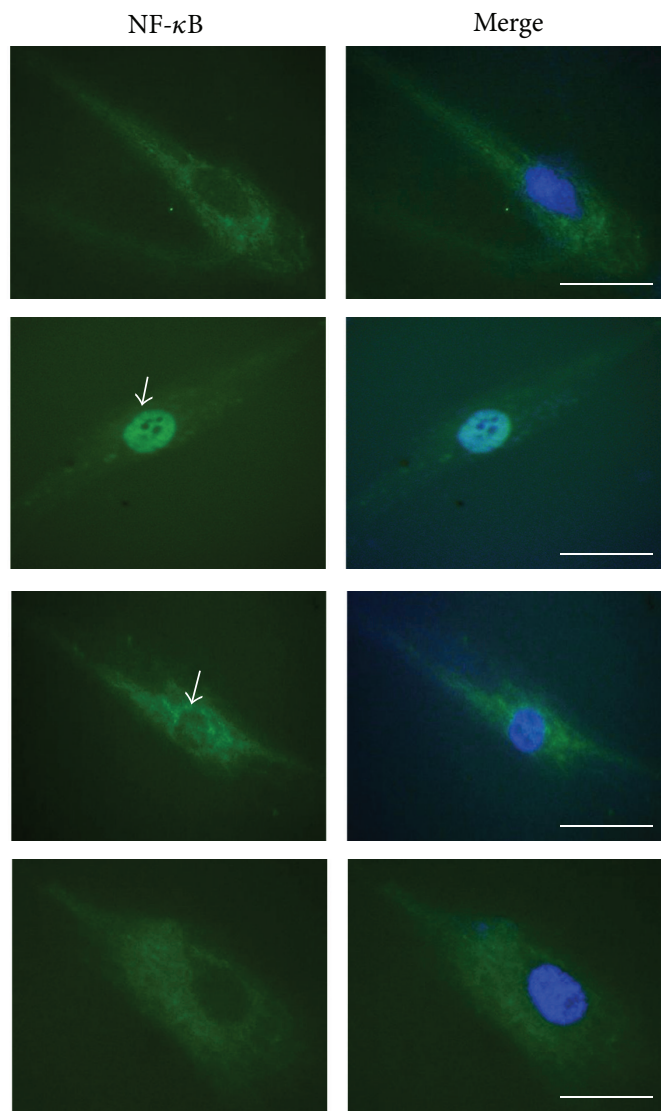

(c)

FIGURE 5: Western blot analyses of NF- $\kappa$ B in the nucleus and cytoplasm. (a) NF- $\kappa$ B nuclear translocation induced by TNF- $\alpha$ was diminished after ANG treatment. ANG treatment alone did not affect NF- $\kappa$ B nuclear translocation. (b) Densitometric analysis of the relative ratio of NF- $\kappa$ B in cells treated with TNF- $\alpha$ alone to those treated with TNF- $\alpha+$ ANG. The experiments were performed in triplicate $\left({ }^{*} P<0.05\right)$. (c) Immunocytochemistry of NF- $\kappa$ B in the nuclei and cytoplasm of HCFs. After treatment with ANG, the cells were fixed and then labeled with an anti-NF- $\kappa$ B antibody. Immunofluorescent images at higher magnification demonstrate attenuation of the expression of NF- $\kappa$ B in nucleus after treatment with ANG ((c) arrow) in cells treated with TNF- $\alpha$ (scale bar, $100 \mu \mathrm{m}$ ).

Since ANG is an inducer of new blood vessel growth, ANG treatment may possibly generate injection on the ocular surface. Because this study is confined to in vitro tests, we cannot exclude the possible adverse effects of ANG in vivo. However, this investigation is the first to report the function of ANG in the inflammatory response. In vivo animal studies are needed to further validate our hypothesis prior to the clinical application of ANG in ocular inflammation.

There is little information in the literature regarding the anti-inflammatory effects of ANG. The ANG functions newly 


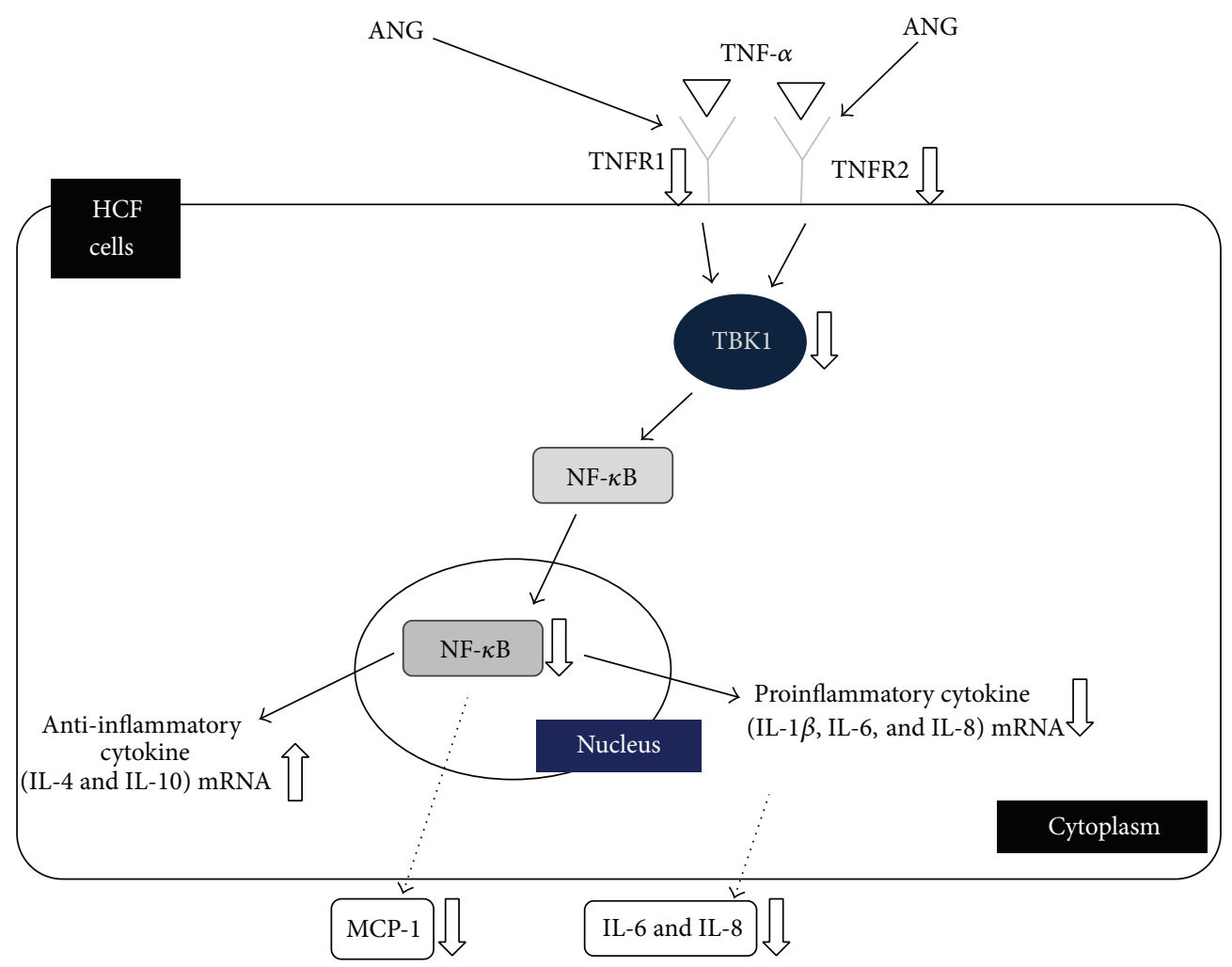

FIGURE 6: Schematic model illustrating the signaling pathway by which ANG suppresses the inflammatory response involving TBK1-mediated NF- $\kappa$ B nuclear translocation in HCFs inflamed by TNF- $\alpha$. ANG reduces the mRNA expression of proinflammatory cytokines (IL- $1 \beta$, -6 , and -8 ) and enhances the mRNA expression of anti-inflammatory cytokines (IL-4 and -10). ANG also inhibits NF- $\kappa$ B nuclear translocation through a reduction in TNFR1 and 2 mRNA expression and TBK1 production. The cascade underlying the effect of ANG results in a decrease in inflammatory cytokines and chemokines such as MCP-1 and IL-6 and -8.

identified in this study indicate that it likely plays a critical role in attenuating inflammation. The findings pointing to the anti-inflammatory effects of ANG in inflamed HCFs shed new light on the treatment of ocular inflammation. We have demonstrated that ANG suppresses the TNF- $\alpha$ induced inflammatory response and NF- $\kappa$ B nuclear translocation through inhibition of TBK1 expression in HCFs. This preliminary evidence suggests that ANG could be a strong candidate for the treatment of corneal inflammation.

\section{Conflict of Interests}

The authors declare that there is no conflict of interests regarding the publication of this paper.

\section{Acknowledgments}

This study was supported by the Basic Science Research Program through the National Research Foundation of Korea (NRF) funded by the Ministry of Education, Science and Technology (NRF-2011-0016922), and by a Grant from the Korea Healthcare Technology R\&D Project, Ministry of Health \& Welfare, Republic of Korea (A121487).

\section{References}

[1] R. Mintz, E. Feller, R. L. Bahr, and S. A. Shah, "Ocular manifestations of inflammatory bowel disease," Inflammatory Bowel Diseases, vol. 10, no. 2, pp. 135-139, 2004.

[2] A. Rothova, M. S. A. Suttorp-van Schulten, W. Frits Treffers, and A. Kijlstra, "Causes and frequency of blindness in patients with intraocular inflammatory disease," British Journal of Ophthalmology, vol. 80, no. 4, pp. 332-336, 1996.

[3] D. Zoukhri, "Effect of inflammation on lacrimal gland function," Experimental Eye Research, vol. 82, no. 5, pp. 885-898, 2006.

[4] S. E. Wilson, R. R. Mohan, R. R. Mohan, R. Ambrósio Jr., J. Hong, and J. Lee, "The corneal wound healing response: cytokine-mediated interaction of the epithelium, stroma, and inflammatory cells," Progress in Retinal and Eye Research, vol. 20, no. 5, pp. 625-637, 2001.

[5] K. S. Na, J. W. Mok, J. Y. Kim, C. R. Rho, and C. K. Joo, "Correlations between tear cytokines, chemokines, and soluble receptors and clinical severity of dry eye disease," Investigative Ophthalmology \& Visual Science, vol. 53, no. 9, pp. 5443-5450, 2012.

[6] N. V. Valentincic, J. D. F. de Groot-Mijnes, A. Kraut, P. Korosec, M. Hawlina, and A. Rothova, "Intraocular and serum cytokine profiles in patients with intermediate uveitis," Molecular Vision, vol. 17, pp. 2003-2010, 2011. 
[7] K. R. VanDerMeid, S. P. Su, K. W. Ward, and J.-Z. Zhang, "Correlation of tear inflammatory cytokines and matrix metalloproteinases with four dry eye diagnostic tests," Investigative Ophthalmology \& Visual Science, vol. 53, no. 3, pp. 1512-1518, 2012.

[8] W. J. King, R. M. Comer, T. Hudde, D. F. P. Larkin, and A. J. T. George, "Cytokine and chemokine expression kinetics after corneal transplantation," Transplantation, vol. 70, no. 8, pp. 1225-1233, 2000.

[9] V. B. Mahajan, C. Wei, and P. J. McDonnell III, "Microarray analysis of corneal fibroblast gene expression after interleukin-1 treatment," Investigative Ophthalmology and Visual Science, vol. 43, no. 7, pp. 2143-2151, 2002.

[10] X. Xi, D. H. McMillan, G. M. Lehmann et al., "Ocular fibroblast diversity: implications for inflammation and ocular wound healing," Investigative Ophthalmology \& Visual Science, vol. 52, no. 7, pp. 4859-4865, 2011.

[11] J. W. Streilein, M. R. Dana, and B. R. Ksander, "Immunity causing blindness: five different paths to herpes stromal keratitis," Immunology Today, vol. 18, no. 9, pp. 443-449, 1997.

[12] Y. Liu, K. Kimura, R. Yanai, T.-I. Chikama, and T. Nishida, "Cytokine, chemokine, and adhesion molecule expression mediated by MAPKs in human corneal fibroblasts exposed to poly(I:C)," Investigative Ophthalmology and Visual Science, vol. 49, no. 8, pp. 3336-3344, 2008.

[13] M. E. Fini, "Keratocyte and fibroblast phenotypes in the repairing cornea," Progress in Retinal and Eye Research, vol. 18, no. 4, pp. 529-551, 1999.

[14] J. T. Daniels, G. Geerling, R. A. Alexander, G. Murphy, P. T. Khaw, and U. Saarialho-Kere, "Temporal and spatial expression of matrix metalloproteinases during wound healing of human corneal tissue," Experimental Eye Research, vol. 77, no. 6, pp. 653-664, 2003.

[15] R. S. Smith, T. J. Smith, T. M. Blieden, and R. P. Phipps, "Fibroblasts as sentinel cells. Synthesis of chemokines and regulation of inflammation," The American Journal of Pathology, vol. 151, no. 2, pp. 317-322, 1997.

[16] J. Maertzdorf, A. D. M. E. Osterhaus, and G. M. G. M. Verjans, "IL-17 expression in human herpetic stromal keratitis: modulatory effects on chemokine production by corneal fibroblasts," Journal of Immunology, vol. 169, no. 10, pp. 5897-5903, 2002.

[17] R. R. Pfister, J. L. Hadclox, and C. I. Sommers, "Injection of chemoattractants into normal cornea: a model of inflammation after alkali injury," Investigative Ophthalmology and Visual Science, vol. 39, no. 9, pp. 1744-1750, 1998.

[18] M. S. Hayden and S. Ghosh, "Shared principles in NF- $\kappa$ B signaling," Cell, vol. 132, no. 3, pp. 344-362, 2008.

[19] S. Miyamoto, M. Maki, M. J. Schmitt, M. Hatanaka, and I. M. Verma, "Tumor necrosis factor $\alpha$-induced phosphorylation of $\mathrm{I} \kappa \mathrm{B} \alpha$ is a signal for its degradation but not dissociation from NF- $\kappa \mathrm{B}$," Proceedings of the National Academy of Sciences of the United States of America, vol. 91, no. 26, pp. 12740-12744, 1994.

[20] V. V. Kravchenko, J. C. Mathison, K. Schwamborn, F. Mercurio, and R. J. Ulevitch, "IKKi/IKKe plays a key role in integrating signals induced by pro-inflammatory stimuli," Journal of Biological Chemistry, vol. 278, no. 29, pp. 26612-26619, 2003.

[21] J. L. Pomerantz and D. Baltimore, "NF- $\kappa$ B activation by a signaling complex containing TRAF2, TANK and TBK1, a novel IKK-related kinase," EMBO Journal, vol. 18, no. 23, pp. 66946704, 1999.
[22] S. M. Reilly, S. H. Chiang, S. J. Decker et al., "An inhibitor of the protein kinases TBK1 and IKK-varepsilon improves obesityrelated metabolic dysfunctions in mice," Nature Medicine, vol. 19, no. 3, pp. 313-321, 2013.

[23] L. Bräuer and F. P. Paulsen, "Tear film and ocular surface surfactants," Journal of Epithelial Biology and Pharmacology, vol. 1, pp. 62-67, 2008.

[24] R. A. Sack, L. Conradi, D. Krumholz, A. Beaton, S. Sathe, and C. Morris, "Membrane array characterization of 80 chemokines, cytokines, and growth factors in open- and closed-eye tears: angiogenin and other defense system constituents," Investigative Ophthalmology and Visual Science, vol. 46, no. 4, pp. 1228-1238, 2005.

[25] Z.-P. Xu, D. M. Monti, and G.-F. Hu, "Angiogenin activates human umbilical artery smooth muscle cells," Biochemical and Biophysical Research Communications, vol. 285, no. 4, pp. 909914, 2001.

[26] A. Hartmann, M. Kunz, S. Köstlin et al., "Hypoxia-induced up-regulation of angiogenin in human malignant melanoma," Cancer Research, vol. 59, no. 7, pp. 1578-1583, 1999.

[27] T. Etoh, K. Shibuta, G. F. Barnard, S. Kitano, and M. Mori, "Angiogenin expression in human colorectal cancer: the role of focal macrophage infiltration," Clinical Cancer Research, vol. 6, no. 9, pp. 3545-3551, 2000.

[28] K. A. Oikonomou, A. N. Kapsoritakis, A. I. Kapsoritaki et al., "Angiogenin, angiopoietin-1, angiopoietin-2, and endostatin serum levels in inflammatory bowel disease," Inflammatory Bowel Diseases, vol. 17, no. 4, pp. 963-970, 2011.

[29] D. S. Osorio, A. Antunes, and M. J. Ramos, "Structural and functional implications of positive selection at the primate angiogenin gene," BMC Evolutionary Biology, vol. 7, article 167, 2007.

[30] L. V. Hooper, T. S. Stappenbeck, C. V. Hong, and J. I. Gordon, "Angiogenins: a new class of microbicidal proteins involved in innate immunity," Nature Immunology, vol. 4, no. 3, pp. 269273, 2003.

[31] M. Srisa-Art, D.-K. Kang, J. Hong et al., "Analysis of proteinprotein interactions by using droplet-based microfluidics," ChemBioChem, vol. 10, no. 10, pp. 1605-1611, 2009.

[32] A. Więdłocha, "Following angiogenin during angiogenesis: a journey from the cell surface to the nucleolus," Archivum Immunologiae et Therapiae Experimentalis, vol. 47, no. 5, pp. 299-305, 1999.

[33] K. Kishimoto, S. Liu, T. Tsuji, K. A. Olson, and G.-F. Hu, "Endogenous angiogenin in endothelial cells is a general requirement for cell proliferation and angiogenesis," Oncogene, vol. 24, no. 3, pp. 445-456, 2005.

[34] S. Wei, X. Gao, J. Du, J. Su, and Z. Xu, “Angiogenin enhances cell migration by regulating stress fiber assembly and focal adhesion dynamics," PLoS ONE, vol. 6, no. 12, Article ID e28797, 2011.

[35] J. W. Fett, D. J. Strydom, R. R. Lobb et al., "Isolation and characterization of angiogenin, an angiogenic protein from human carcinoma cells," Biochemistry, vol. 24, no. 20, pp. 54805486, 1985.

[36] J. F. Riordan and B. L. Vallee, "Human angiogenin, an organogenic protein," British Journal of Cancer, vol. 57, no. 6, pp. 587-590, 1988.

[37] N. Yoshioka, L. Wang, K. Kishimoto, T. Tsuji, and G.-F. Hu, "A therapeutic target for prostate cancer based on angiogeninstimulated angiogenesis and cancer cell proliferation," Proceedings of the National Academy of Sciences of the United States of America, vol. 103, no. 39, pp. 14519-14524, 2006. 
[38] U. W. Nilsson, A. Abrahamsson, and C. Dabrosin, "Angiogenin regulation by estradiol in breast tissue: tamoxifen inhibits angiogenin nuclear translocation and antiangiogenin therapy reduces breast cancer growth in vivo," Clinical Cancer Research, vol. 16, no. 14, pp. 3659-3669, 2010.

[39] S. Li, S. Ibaragi, and G.-F. Hu, "Angiogenin as a molecular target for the treatment of prostate cancer," Current Cancer Therapy Reviews, vol. 7, no. 2, pp. 83-90, 2011.

[40] F. Lioté, R. Champy, M. Moenner, B. Boval-Boizard, and J. Badet, "Elevated angiogenin levels in synovial fluid from patients with inflammatory arthritis and secretion of angiogenin by cultured synovial fibroblasts," Clinical and Experimental Immunology, vol. 132, no. 1, pp. 163-168, 2003.

[41] I. E. Koutroubakis, C. Xidakis, K. Karmiris, A. Sfiridaki, E. Kandidaki, and E. A. Kouroumalis, "Serum angiogenin in inflammatory bowel disease," Digestive Diseases and Sciences, vol. 49, no. 11-12, pp. 1758-1762, 2004.

[42] L. V. Hooper, T. S. Stappenbeck, C. V. Hong, and J. I. Gordon, "Angiogenins: a new class of microbicidal proteins involved in innate immunity," Nature Immunology, vol. 4, no. 3, pp. 269273,2003

[43] X.-H. Xie, N. Zang, S.-M. Li et al., "Resveratrol inhibits respiratory syncytial virus-induced IL-6 production, decreases viral replication, and downregulates TRIF expression in airway epithelial cells," Inflammation, vol. 35, no. 4, pp. 1392-1401, 2012.

[44] E. Marchlik, P. Thakker, T. Carlson et al., "Mice lacking Tbk1 activity exhibit immune cell infiltrates in multiple tissues and increased susceptibility to LPS-induced lethality," Journal of Leukocyte Biology, vol. 88, no. 6, pp. 1171-1180, 2010.

[45] T. Yu, Y. S. Yi, Y. Yang, J. Oh, D. Jeong, and J. Y. Cho, “The pivotal role of TBK1 in inflammatory responses mediated by macrophages," Mediators of Inflammation, vol. 2012, Article ID 979105, 8 pages, 2012.

[46] D. Hammaker, D. L. Boyle, and G. S. Firestein, "Synoviocyte innate immune responses: tank-binding kinase-1 as a potential therapeutic target in rheumatoid arthritis," Rheumatology, vol. 51, no. 4, pp. 610-618, 2012.

[47] K. Migita and T. Nakamura, "TBK1: a potential therapeutic target in RA," Rheumatology, vol. 51, no. 4, pp. 588-589, 2012.

[48] J. Zhu, W. Yong, X. Wu et al., "Anti-inflammatory effect of resveratrol on TNF- $\alpha$-induced MCP-1 expression in adipocytes," Biochemical and Biophysical Research Communications, vol. 369, no. 2, pp. 471-477, 2008.

[49] S. L. Deshmane, S. Kremlev, S. Amini, and B. E. Sawaya, "Monocyte chemoattractant protein-1 (MCP-1): an overview," Journal of Interferon and Cytokine Research, vol. 29, no. 6, pp. 313-325, 2009.

[50] K. G.-J. Ooi, G. Galatowicz, V. L. Calder, and S. L. Lightman, "Cytokines and chemokines in uveitis-is there a correlation with clinical phenotype?" Clinical Medicine and Research, vol. 4, no. 4, pp. 294-309, 2006.

[51] H. Ghasemi, T. Ghazanfari, R. Yaraee, S. Faghihzadeh, and Z. M. Hassan, "Roles of IL-8 in ocular inflammations: a review," Ocular Immunology and Inflammation, vol. 19, no. 6, pp. 401412, 2011.

[52] I. Lema, T. Sobrino, J. A. Durán, D. Brea, and E. Díez-Feijoo, "Subclinical keratoconus and inflammatory molecules from tears, British Journal of Ophthalmology, vol. 93, no. 6, pp. 820824, 2009.

[53] N. Tuaillon, D. F. Shen, R. B. Berger, B. Lu, B. J. Rollins, and C.-C. Chan, "MCP-1 expression in endotoxin-induced uveitis,"
Investigative Ophthalmology and Visual Science, vol. 43, no. 5, pp. 1493-1498, 2002.

[54] M. Rojas, W. Zhang, D. L. Lee et al., "Role of IL-6 in angiotensin II-induced retinal vascular inflammation," Investigative Ophthalmology and Visual Science, vol. 51, no. 3, pp. 1709-1718, 2010.

[55] C. Gabay, "Interleukin-6 and chronic inflammation," Arthritis Research and Therapy, vol. 8, supplement 2, article S3, pp. 1-6, 2006.

[56] S. Akira, T. Taga, and T. Kishimoto, "Interleukin-6 in biology and medicine," Advances in Immunology, vol. 54, pp. 1-78, 1993.

[57] T. Kishimoto, "Interleukin-6: from basic science to medicine40 years in immunology," Annual Review of Immunology, vol. 23, pp. 1-21, 2005.

[58] A. Harada, N. Sekido, T. Akahoshi, T. Wada, N. Mukaida, and K. Matsushima, "Essential involvement of interleukin-8 (IL-8) in acute inflammation," Journal of Leukocyte Biology, vol. 56, no. 5, pp. 559-564, 1994.

[59] R. S. Izzo, K. Witkon, A. I. Chen, C. Hadjiyane, M. I. Weinstein, and C. Pellecchia, "Neutrophil-activating peptide (interleukin8 ) in colonic mucosa from patients with Crohn's disease," Scandinavian Journal of Gastroenterology, vol. 28, no. 4, pp. 296300, 1993.

[60] P. Gibson and O. Rosella, "Interleukin 8 secretion by colonic crypt cells in vitro: response to injury suppressed by butyrate and enhanced in inflammatory bowel disease," Gut, vol. 37, no. 4, pp. 536-543, 1995.

[61] P. Conti and M. DiGioacchino, "MCP-1 and RANTES are mediators of acute and chronic inflammation," Allergy and Asthma Proceedings, vol. 22, no. 3, pp. 133-137, 2001.

[62] C. Viedt, R. Dechend, J. Fei, G. M. Hänsch, J. Kreuzer, and S. R. Orth, "MCP-1 induces inflammatory activation of human tubular epithelial cells: involvement of the transcription factors, nuclear factor- $\kappa \mathrm{B}$ and activating protein-1," Journal of the American Society of Nephrology, vol. 13, no. 6, pp. 1534-1547, 2002.

[63] C. Marie, C. Pitton, C. Fitting, and J.-M. Cavaillon, "Regulation by anti-inflammatory cytokines (IL-4, IL-10, IL-13, TGF $\beta$ ) of interleukin- 8 production by LPS- and/or TNF $\alpha$-activated human polymorphonuclear cells," Mediators of Inflammation, vol. 5, no. 5, pp. 334-340, 1996.

[64] S. W. Lee, Y. S. Hong, C. M. Chun et al., "Anti-inflammatory effects of IL-4 and IL-10 on human polymorphonuclear leukocytes," Journal of Korean medical science, vol. 17, no. 1, pp. 7-14, 2002.

[65] R. de Waal Malefyt, J. Haanen, H. Spits et al., "Interleukin 10 (IL10) and viral IL-10 strongly reduce antigen-specific human T cell proliferation by diminishing the antigen-presenting capacity of monocytes via downregulation of class II major histocompatibility complex expression," Journal of Experimental Medicine, vol. 174, no. 4, pp. 915-924, 1991.

[66] T. W. Mak and W. C. Yeh, "Signaling for survival and apoptosis in the immune system," Arthritis Research, vol. 4, supplement 3, pp. S243-S252, 2002.

[67] T. S. Blackwell and J. W. Christman, "The role of nuclear factor$\kappa \mathrm{B}$ in cytokine gene regulation," American Journal of Respiratory Cell and Molecular Biology, vol. 17, no. 1, pp. 3-9, 1997.

[68] M. C. Muñoz, J. F. Giani, M. A. Mayer, J. E. Toblli, D. Turyn, and F. P. Dominici, "TANK-binding kinase 1 mediates phosphorylation of insulin receptor at serine residue 994: a potential link between inflammation and insulin resistance," Journal of Endocrinology, vol. 201, no. 2, pp. 185-197, 2009. 
[69] L. A. Hart, V. L. Krishnan, I. M. Adcock, P. J. Barnes, and K. F. Chung, "Activation and localization of transcription factor, nuclear factor- $\kappa \mathrm{B}$, in asthma," American Journal of Respiratory and Critical Care Medicine, vol. 158, no. 5, pp. 1585-1592, 1998.

[70] P. P. Tak and G. S. Firestein, "NF- $\kappa$ B: a key role in inflammatory diseases," Journal of Clinical Investigation, vol. 107, no. 1, pp. 7-11, 2001.

[71] T. Collins and M. I. Cybulsky, "NF- $\kappa$ B: pivotal mediator or innocent bystander in atherogenesis?" Journal of Clinical Investigation, vol. 107, no. 3, pp. 255-264, 2001.

[72] H. Asahara, M. Asanuma, N. Ogawa, S. Nishibayashi, and H. Inoue, "High DNA-binding activity of transcription factor $\mathrm{NF}-\kappa \mathrm{B}$ in synovial membranes of patients with rheumatoid arthritis," Biochemistry and Molecular Biology International, vol. 37, no. 5, pp. 827-832, 1995. 


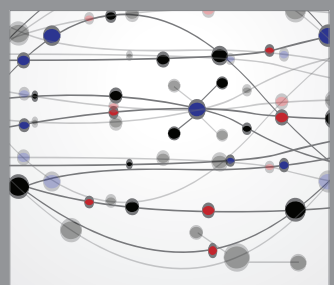

The Scientific World Journal
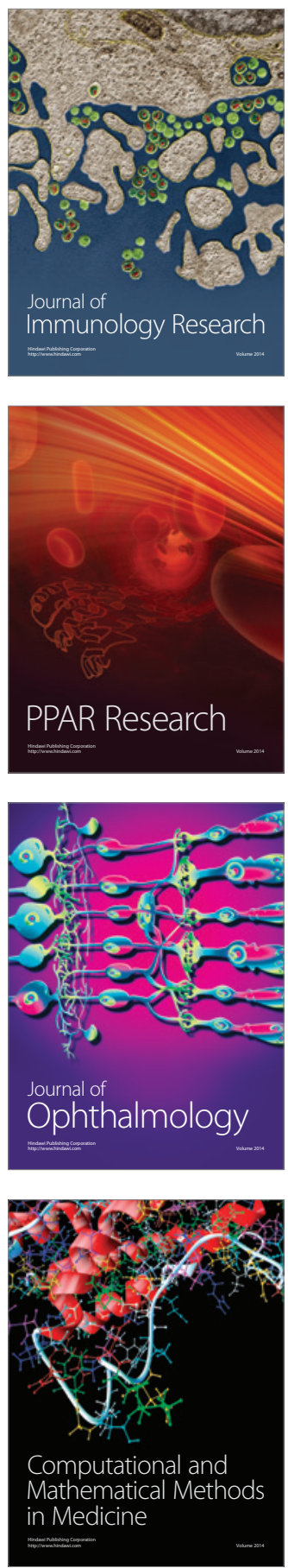

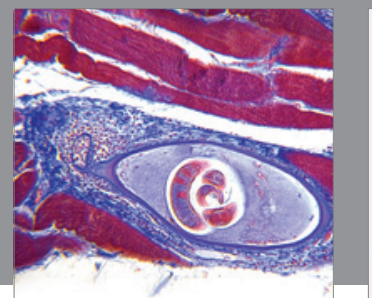

Gastroenterology

Research and Practice
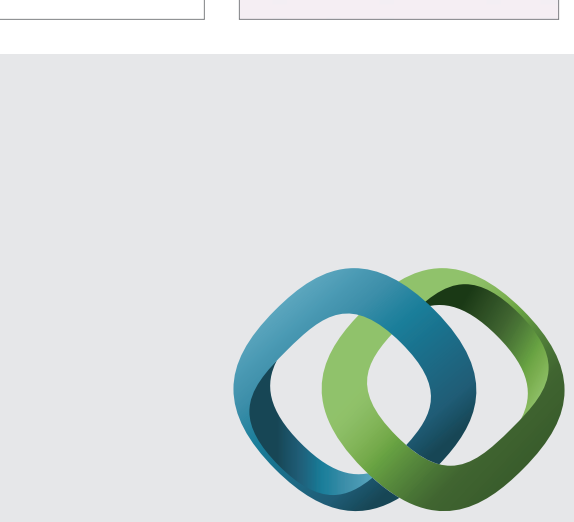

\section{Hindawi}

Submit your manuscripts at

http://www.hindawi.com
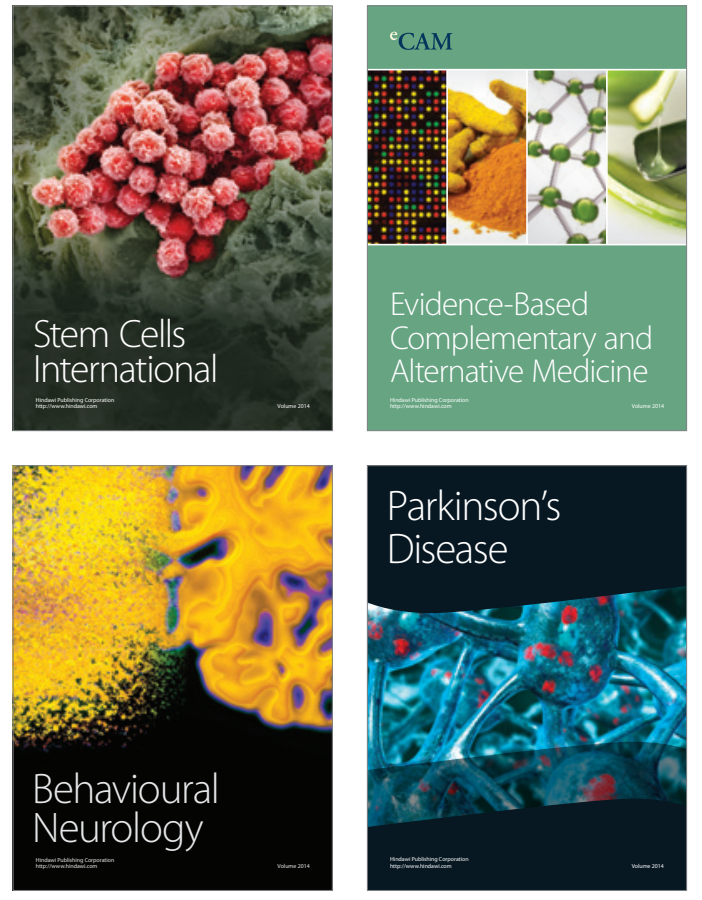
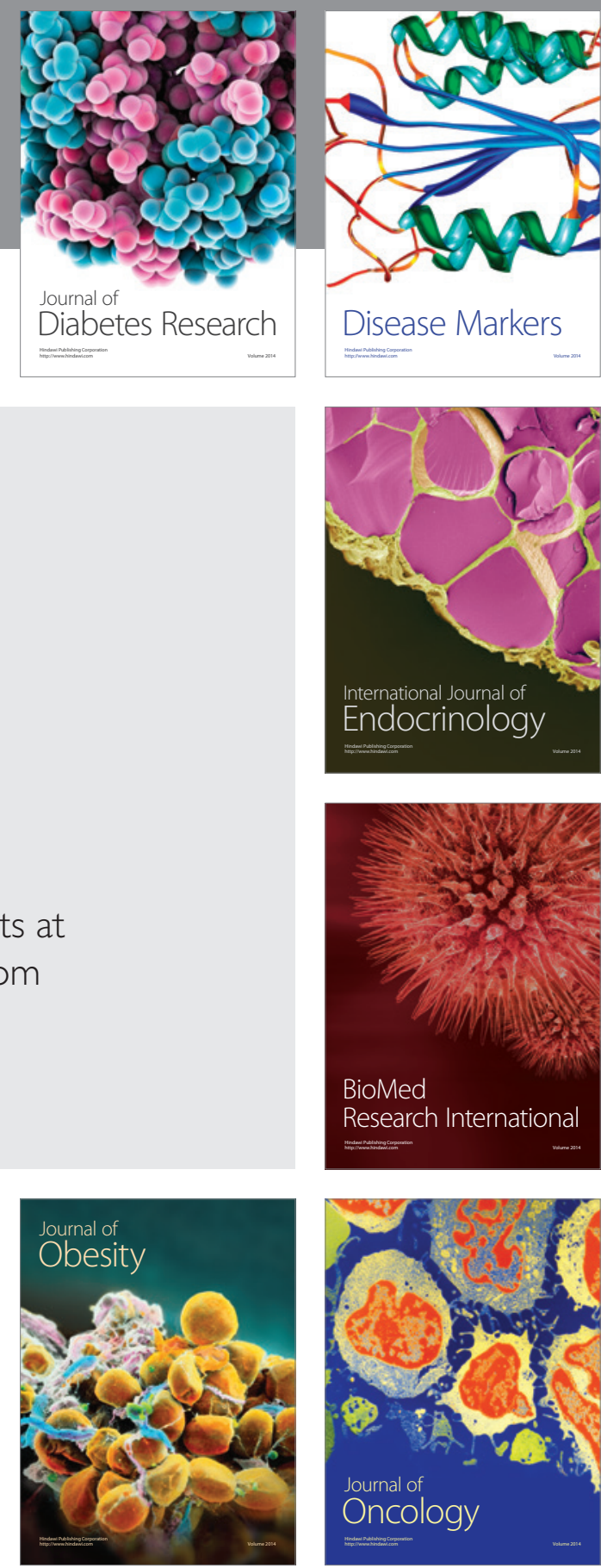

Disease Markers
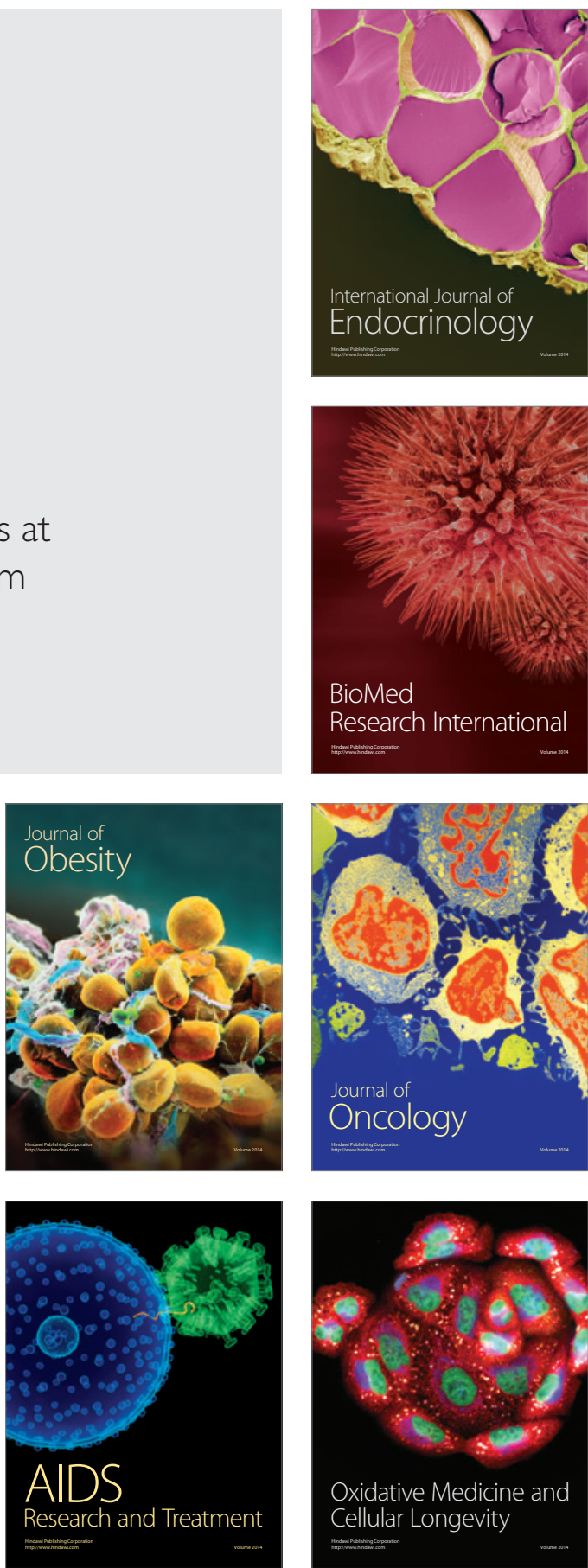